\title{
FILE COPV Sept. 1987 GATT Law, Agricultural Trade, and Developing Countries: Lessons from Two Case Studies
}

\author{
Surakiart Sathirathai and Ammar Siamwalla
}

This article examines the relevance and applicability of the law of the General Agreement on Tariffs and Trade (GATT) to two specific problems faced by Thailand: the negotiations of a voluntary export restraint agreement on cassava with the European Economic Community and the increased subsidies on rice given by the United States under the Food Security Act of 1985.

In the case of cassava, Thailand appears to have had parts of GATT law on its side, but the government was very reluctant to use the law to its own advantage. This reluctance was due to unclear procedures under GATT as to how to make effective use of these legal advantages. On the rice subsidy issue, conversely, the substantive law is unclear and provides limited protection for competing exporters.

The wider lesson drawn from the two cases is that GATT's law should be modified and its role reevaluated so that both developed and developing countries can participate more fully in the GATT system. This will be necessary if the GATT's laws are to become useful instruments in the hands of developing countries in their bilateral negotiations with contracting parties which are the more powerful economically.

Agricultural trade has the pride of place in the new round of multilateral trade negotiations (MTN), but in the brave new world that is to come after this latest round, the landscape of international agricultural trade will remain substantially unchanged. No doubt, concessions will be made during the round and some order put into the present chaos of subsidies, but there will still be voluntary export restraints (VERs), and the subsidy rules will still be full of exceptions, or worse, ambiguities. After and even during the upheaval of the MTN, normal life will continue, bilateral deals will be cut and adjustments will be sought by some countries against actions that seriously affect their economic interests.

The GATT is seen in this article as the backdrop against which a number of

Surakiart Sathirathai is lecturer, Faculty of Law, Chulalongkorn University, Bangkok. Ammar Siamwalla is program director, agricultural and rural development, Thailand Development Research Institute, Bangkok. The section in this article on cassava trade was based on extensive research carried out by the Thailand Development Research Institute and financed by the Cassava Trust Fund of the Cassava Trade Association, Bangkok. The authors wish to express their gratitude to Robert Hudec for his constructive comments.

Copyright (C) 1987 by the International Bank for Reconstruction and Development / THE WORLD BANK. 
bilateral trade negotiations take place. The importance of GATT law, inasmuch as it is implicitly accepted as a constraint on the behavior of sovereign nations, lies in the ever-so-slight shift in bargaining power that occurs as a result of its existence. ${ }^{1}$ Consequently, the next round of MTN should examine the workings of GATT law in this (usually neglected) context.

The task of this article is to persuade readers to pay attention to the "normal" type of international agricultural negotiations, which are usually bilateral and commodity-specific. From our point of view, a successful MTN round is one in which the conditions of "normality" improve the negotiating or trade position of the weaker developing countries. The mode of analysis we shall use is the case study method. We examine in depth (in sections I and II) two problems of agricultural trade faced by Thailand in the last few years, one involving trade with the European Economic Community (EEC), proponent of the conciliatory school of GATT law, and the other involving the United States, a proponent of the adversarial school. The first case concerns a VER while the second involves an export promoting subsidy, the legal status of which is still untested. Both issues are of concern in the (MTN). The two cases studied allow us to examine problems arising out of the application of GATT law in the final section of the article.

\section{Thai-EEC Cassava Negotiations}

\section{Thai-EEC Cassava Trade until 1982}

Since the inception of its Common Agricultural Policy (CAP), the EEC has allowed its cereal prices to stay well above world price levels. The mechanism used to maintain these prices is a variable import levy or, if the commodity is exported, a variable export restitution (that is, a subsidy for exports). Between 1977-78 and 1979-80, the nominal rate of protection for cereals averaged about 90 percent (Australia 1985, table 4). These high prices have discouraged consumption of cereals in the EEC, particularly as animal feed.

It was very quickly found that noncereal substitutes could be used as animal feed just as well. Thus, 0.77 kilogram of cassava, which is almost entirely starch, can be mixed with 0.20 kilogram of soybean cakes, a protein-rich substance, to replace 1.00 kilogram of barley in pork rations (Koester 1982, p. 35). Similar proportions apply for other cereals in other rations. Furthermore, both cassava and soybeans are subject to the relatively low import levies of 6 and 0 percent respectively. The EEC bound these tariffs in the Dillon and Kennedy MTN rounds.

The cassava trade with the EEC was initiated by Brazil and Indonesia, both of which have large cassava production, but they were quickly overtaken by Thai-

1. The view that international law can serve as a constraint on powerful states and thus provide bargaining power for developing countries is in line with the approach taken by various legal scholars. For representative examples see Schachter (1977) and Friedmann, Henkin, and Lissitzyn (1972). 
land, which until then had been a relatively small producer. Between 1967 and 1980 , production of cassava roots in Thailand doubled every three to four years. By 1982 the EEC market for cassava was worth 770 million U.S. dollars to Thailand, making cassava its second largest commodity export after rice.

Within the EEC, most Thai cassava ends up in the Federal Republic of Germany and the Netherlands. It is used entirely for animal feed, principally for pigs although dairy cattle take up about 30 percent of the total. These two countries are the principal users of Thai cassava because they are Europe's major pork producers, they (particularly the Netherlands) have good inland waterway systems that connect the ports to the feed compounding mills, and they peg their green exchange rates at a more depreciated level than the official exchange rate and thus shifted relative prices in favor of cassava usage as against cereals. ${ }^{2}$

The surge of cassava imports reduced the demand for cereals, imposing additional costs on the EEC budget through lower import levy revenue or larger export restitution payments on cereals. The cheap feed benefits the livestock producers (particularly pork producers) in Germany and the Netherlands at the expense of France and Italy, which resulted in French pressure on the EEC to restrain trade. Once the pressure began, the Thais tried to obtain the support of the beneficiaries in their negotiations with the EEC, with meager results.

The emergence of Thailand as a dominant supplier of cassava to the EEC can be explained by its comparative advantage, not so much in production as in transport. Cassava is a plant that can grow on relatively poor lands, which many tropical countries have in abundance. As a relatively low-valued commodity, however, efficient transport is essential for the cassava trade to grow. With an excellent road network, Thailand was in a good position to keep transport costs low. In 1982, farmers in the main producing area about 240 kilometers $(150$ miles) from the port were able to get 76 percent of the port price, this for a commodity that starts out its journey as fresh roots fetching only 3 cents per kilogram.

As the scale of the trade grew, Thailand was able to reinforce its comparative advantage. Large investments were made in loading facilities as well as in processing. The cassava exported is actually a crude product. After harvest, the cassava is broken into smaller pieces, called chips, and then sun dried. With the increasing scale of trade, the chips were "pelletized," a process in which chips are squeezed through holes so that they emerge roughly the shape and size of cigarettes. This additional transformation of the product is solely to economize on transport costs: more can be packed into ship holds, and less dust is generated at the time of loading and unloading.

2. The green exchange rate is the currency used to translate the administered prices for agricultural goods set by the EEC as a whole (expressed in European Currency Units), into national prices (expressed in domestic currencies). Administered prices include threshold, intervention, and target prices, which together set the structure of prices in the EEC. When a particular green exchange rate is set differently from the official exchange rate, it allows the levels of agricultural prices in that country to differ from the European norm (see Ritson and Tangermann 1979). 
The Thai share of total European cassava imports in 1980-82 amounted to 87 percent. But even then, new exporters were entering the scene. In 1981, China, for example, exported 607,000 tons or 9 percent of the total, reaching that level after only entering the trade in 1979.

In the final analysis, the cassava trade is an artificial one, made possible only by the EEC policy of keeping cereal prices high. Thailand could find very few other outlets for its cassava pellets. Indeed, Thai animal feed compounders found that, at the prices the pellets were fetching in the EEC, it was better to allow the cassava to be shipped to Rotterdam than to use it as feed themselves. For them, using cereals is more economical.

The cassava trade to the EEC has always posed a dilemma for the Thai government. It is clearly a very profitable trade, but also a perilous one, given its dependence on policy decisions made in a single market. Many voiced their concern and suggested some method to prevent too heavy a reliance on this one commodity. For although at their height cassava exports were about 13 percent of total exports, they formed a very important part of the cash incomes of farmers in the Northeast, Thailand's poorest region.

Against this, it may be noted that cassava is a relatively easy crop to grow, requiring little cash outlay in its cultivation. Consequently there is considerable flexibility on the part of the farmers, and estimates of supply elasticity usually yield figures of around 1 . The investments in transport and processing mentioned earlier are not specific to cassava, except for the pelletizing plants which contribute less than 10 percent of the final value of the exported cassava. Despite the EEC's budgetary problems, it has always seemed unlikely that there would be a rapid dismantling of the protection policy for cereals in the EEC. If a decline in protection were to be gradual, Thailand would be able to cope with the adjustment costs fairly easily.

The Thai government opted to do nothing and let the trade grow until it was forced to restrain exports by the EEC, for the European response to the cassava trade was not to dismantle the protection on cereals, but to erect barriers against cassava.

\section{The 1982 Cassava Trade Agreement}

In 1982, the EEC entered into major agreements with each of the three cassavaexporting countries, Brazil, Indonesia, and Thailand. Because the EEC is bound by its tariff concession commitment under the Kennedy Round in 1967, it had to follow procedures set forth in Article XXVIII ("Modification of Schedules") of the GATT before it could modify such concessions. ${ }^{3}$ Article XXVIII requires the concession granter who wishes to modify the concession to negotiate and seek agreement with the principal supplier, the initial supplier with which the granter negotiated the concession, and any suppliers who may have a substantial inter-

3. These tariff concessions generally called "bindings," are contained in a list termed "tariff schedules," which under Article II of the GATT are legally binding. 
est. The negotiation process may also include compensatory adjustments made by the party requesting the modifications. ${ }^{4}$ In 1982 Brazil and Indonesia, both GATT contracting parties, were treated as the initial supplier and principal supplier, respectively, under the GATT. Because Thailand was not at that time a contracting party to GATT, the EEC was not obliged to follow Article XXVIII procedures with respect to Thailand.

The essence of the agreements with these two countries is that both temporarily permit the EEC, within the life of the agreements, to unbind its tariff concession obligation under the GATT in order to set up a tariff quota system (EEC $1982 \mathrm{a}, 1982 \mathrm{~b})$. The agreement allows a prohibitively high tariff to be levied on the amount in excess of the quota. The agreement allocated generous and rising quotas to GATT contracting parties between the years 1982-86 (588,235 metric tons in 1982 rising to 970,590 tons in 1986) and assured Indonesia of 85 percent of all quotas allotted to GATT contracting parties. The increased quota allowed seemed to be a part of the compensatory adjustment under Article XXVIII of the GATT. Both countries also agreed that the EEC would be the import licensor. The two agreements were due to expire on December 31, 1986, but could be extended for another three years unless denounced by either party to each agreement one year before the expiration date. In 1982 the parties to both agreements notified the GATT that both Brazil and Indonesia had agreed to the modification of the EEC's tariff commitment (unbinding) under the Kennedy Round of 1967.

The EEC convinced Thailand, at that time not yet a GATT contracting party, to enter into a voluntary export restraint agreement with it. The agreement is euphemistically entitled the "Cooperation Agreement between the Kingdom of Thailand and the European Economic Community on Manioc Production, Marketing, and Trade" (hereinafter referred to as the 1982 Agreement; (EEC 1982c). The major features of the 1982 Agreement are described briefly as follows. As the EEC entered into the agreement with Thailand as a non-GATT contracting party, there were no Article XXVIII negotiations involved. The quota agreed upon was a declining one: 5 million tons in 1983 and in 1984 (with an extra 500,000 tons allowed for either of the two years) and 4.5 million tons for 1985 and 1986 (also with an extra 450,000 tons allowed for either of the two years). The Agreement allowed Thailand to issue the export licenses, upon presentation of which, the EEC issues import licenses for the Thai products. The EEC agreed to provide assistance for rural development and crop diversification projects in Thailand of 75 million Ecu's (European Currency Units) for the period 1982-86. The EEC also loosely incurs an obligation to secure Thailand's position on the EEC cassava market against increases of cassava imports from other countries, and to "bear in mind" the import of other carbohydrate prod-

4. In the so-called Chicken War between the United States and the EEC, when Germany raised its tariff against import of poultry from the United States upon joining the EEC, the United States was allowed to withdraw concessions on a volume of trade equal to the volume that would have occurred under the poultry concession in a representative period (see Walker 1964; Hartwig and Tangermann 1987). 
ucts which could compete directly with cassava. While, the 1982 Agreement was scheduled to expire in December 1986, it could be extended for a further threeyear period if neither party denounced it one year before the expiration date.

The Thai negotiating power prior to the signing of the 1982 Agreement, and Thai officials' perception of the trade benefits and security provided under the agreement, played an important role in their decision not to accept simple extension of this 1982 Agreement for three years after December 1986. First, as Thailand once exported as much as 7.3 million tons of cassava to the EEC in the absence of the quantitative restriction, the agreed quota was relatively small. The officials appear to have taken the view that the restricted and declining quota was balanced out by the arrangement which made Thailand the export licensor, allowing the quota rent accrue to it. Further, since the EEC financial assistance to Thailand is given through the Ministry of Agriculture and Cooperatives, there was strong support for the 1982 Agreement from that ministry. Finally, there was a widespread perception that, as Thailand was not a GATT member, it had little bargaining power against the EEC. It was felt that the terms of the agreement, although not as good as a free trade regime, were probably the best Thailand could obtain, for a probable alternative was a unilateral move by the EEC.

There was some opposition to this perspective within Thailand. Many felt that the government should delay the agreement as long as possible, at least until Thailand became a GATT member. However, the EEC strongly hinted that they would apply Article XXXV (which provides for nonapplicability of specific GATT obligations between particular contracting parties) if Thailand did become a GATT member without signing the VER. Some Thais felt that the declining quota was not fair, in the sense that a most-favored-nation (MFN) treatment (to which Thailand is entitled from an earlier agreement between the EEC and the Association of South East Asian Nations) of a tariff quota can be construed to require that Thailand at least should have maintained its share of EEC imports vis-à-vis Indonesia and Brazil. ${ }^{5}$ Finally, the obligation on the EEC to "bear in mind" the impact of cassava and other carbohydrate products imported from other countries on Thailand was thought to be too vague. This concern is supported by the fact that while the EEC has been restricting the cassava exported from Thailand, it has done very little to restrict the U.S. exports of citrus pulp and corn gluten, two other major cereal substitutes.

These perceptions and arguments relating to the 1982 agreement were to play an important role in 1985 when the decision to extend or denounce the Agreement again became a public issue in Thailand. A point of note here is that during the 1982-86 period, Brazil and Indonesia did not fill their annual quota allocations while the quota for Thailand was binding. Although the EEC used the GATT

5. To apply the MFN concept to a tariff quota, the principle implicit in the GATT's Article XIII (2) (nondiscriminatory administration of quantitative restrictions) is applied. The agreements between the EEC and the three countries started at the same time in 1982, and the previous representative period of three years prior to 1982 would have supported the belief that this was an unfair quota allocation. 
to its own benefit in 1982, in 1985 its representatives told the Thai negotiators frequently that appealing to the GATT is "legalistic" and therefore inadvisable.

$$
\text { The Negotiations of 1985-86 }
$$

The issue in 1985 was whether Thailand should renounce the 1982 Agreement, due to expire in December 1986. The key element for the decision lay in Thailand's legal position consequent upon its entry into the GATT. The issue became a public debate when some government officials and Cabinet members who were to negotiate the VER said that Thailand should extend the 1982 Agreement for three more years. To them, the Agreement provided certainty, for it guaranteed the amount Thailand could export to the EEC. The GATT was seen as a paper tiger not to be relied on; a bilateral pact was viewed as more dependable than the EEC's and Thailand's commitments to a multilateral GATT.

Others took the view that, since Thailand had become a contracting party to the GATT in 1982, it should be able to benefit from GATT principles, in particular the bound concession given in the Kennedy Round to allow cassava to enter the EEC subject to 6 percent tariff without any quantitative restriction. ${ }^{6}$ They argued that the 1982 unbinding, negotiated with Brazil and Indonesia, was temporary and was due to end in 1986. Under Article XXVIII of the GATT, further continuation of the unbinding could only be reached after negotiations with all contracting parties having rights under the bound tariff. Those of this view argued that since Thailand was now a GATT contracting party, it had rights to the binding, replacing Indonesia as the principal supplier of cassava to the EEC. ${ }^{7}$ Thailand's rights under the binding would then have been its main negotiating weapon. This view of Thailand's rights under the GATT was advanced during the preliminary negotiations conducted at the technical (nonministerial) level in Bangkok in October 1985.

As for the EEC's attitude before and after this meeting, in both formal and informal sessions, a somewhat legalistic position appears to have been taken by the EEC, despite its often reiterated suggestion to the Thai government not to be too legalistic. For example, the EEC argued that the permission granted to the EEC by Indonesia to unbind its obligation under the Kennedy Round was a permanent one, and there was thus no need for it to renegotiate with Thailand or any GATT contracting parties. To us, this argument is untenable. The EECIndonesia Agreement of 1982 was clearly temporary in nature, its continuation being contingent upon the absence of denunciation by either the EEC or Indone-

6. Thailand is entitled to this binding through the Most-Favored-Nation Principle of Article I of the GATT. Hudec suggested that there could have been a reservation or side agreement concerning cassava at Thailand's accession to the GATT. While the EEC might have made a reservation on its cassava concession, the schedule indicated no such reservation. Our inquiries with Thai negotiators involved in the accession to the GATT and the 1982 Agreement indicated also that no oral or written side agreement was arranged.

7. Thailand's position as the principal supplier of cassava was confirmed by Ake Linden, legal advisor to the director general of the GATT in his letter to the Thai ambassador to the United Nations at Geneva, dated November 22, 1985. 
sia one year before the expiration date in December 1986. In the letter to the GATT, the EEC used the phrase "negotiations were conducted in accordance with Article XXVIII of GATT with an aim of suspending temporarily the Community's tariff concession ..." (emphasis added), (EEC 1982a, 1982b). In the annex to a letter to the Director-General of the GATT signed jointly by the EEC and Indonesian Delegates, there is a statement "Concessions to be suspended until 31st December 1986." No other statement in the letter or the annex indicates that the suspension is permanent or indefinite (GATT 1982). And Article 2 of both Agreements with Indonesia and Brazil stipulates that the arrangements will remain in force until December 31, 1986 (EEC 1982a, 1982b).

EEC officials also dropped hints that the binding in the Kennedy round applied only to cassava chips and not to pellets. This possible interpretation is countered by the Custom Cooperation Council Nomenclature (CCCN) and the EEC's own customs law. While the 1967 binding under Subheading 07.06 of the CCCN did not explicitly include cassava pellets, the Explanatory Note of the CCCN issued in 1968 states that Subheading 07.06 includes cassava pellets. This Explanatory Note is supported by EEC practice and the 1982 inclusion of cassava pellets into its own Common Custom Tariff (СCT) Subheading 07.06 A (II).

Thailand did not strongly dispute the EEC's arguments, nor did it assert its principal supplier's rights under Article XXVIII of the GATT. It did request that its quota be enlarged to include the potential imports of Spain and Portugal, who were then becoming members of the EEC and therefore subject to the cassava tariff quota restriction if an agreement regulating cassava trade were to continue. The EEC's (correct) response was that under GATT Article XXIV (5) and (6) it was under no legal obligation to increase the quota for Thailand because neither country had any tariff binding on cassava imports before joining the Community. ${ }^{8}$

In contrast to the EEC's legalistic approach to the negotiation (when such an approach suited its position), Thailand was reluctant to apply GATT law to strengthen its position in the trade negotiations or to achieve its objective. The question, often raised in domestic discussions, as to whether one could be confident that Thailand would "win the case" in the GATT's formal panel proceedings shows a misperception of the use of GATT mechanisms in trade negotiations. There is a difference between the use of the GATT dispute settlement mechanism to reach a satisfactory agreement and the winning or losing of a domestic court decision. By its reluctance to employ GATT law, the Thai government relinquished its position as a negotiating partner and ineluctably sank into the role of supplicant.

Later in 1985, the Thai minister of commerce went to Brussels to negotiate a

8. Article XXVIII provides that parties that withdraw negotiated concessions may be required to compensate other contracting parties. The establishment of a customs union affecting concessions adopted previously by new members must also conform to the compensatory procedures of Article XXVIII. Since Spain and Portugal had not negotiated concessions on cassava, they were not required by Article XXIV (6) to follow Article XXVIII procedure. 
new cassava agreement. A Draft Protocol was initialed extending the 1982 Agreement from 1987 to 1990 ; with the trade quota increased from 4.975 to 5.25 million tons per year from 1987 to 1990 . The EEC acceded in writing that the 6 percent tariff under the CCCN subheading 07.06 (or 07.06A of the Common Custom Tariff) cover both Thai cassava chips and pellets. The EEC noted, however, that such acceptance of the product coverage under these tariff headings holds only during the life of the Protocol. More important, Article 3 of the Draft Protocol was phrased so that it appears that Thailand accepted the Ecc's claim that its cassava pellets are made from flour or meal, which would subject Thai cassava exports to a very high tariff level. ${ }^{9}$ The EEC could then claim that Thailand had accepted in writing that the Draft Protocol includes chips and pellets in 07.06 only as an exception. Finally, the Draft Protocol took into consideration that since entry into force of the 1982 Agreement, Thailand has become a contracting party to the GATT. That was the last time the GATT was mentioned in the draft: there was no recognition of Thailand's claimed position as a principal supplier.

The outcome of the negotiation once again demonstrates Thai reluctance to insist on what many felt were clear and favorable legal principles under the GATT. The government immediately accepted the increased quota allowance, despite the fact that Thailand had another year (1986) to negotiate the quota and other issues. Given the estimated 8 million tons per year of possible exports in the absence of quantitative restrictions, it is arguable that a quota of only 5.25 million tons warranted further assertion of Thailand's rights under the GATT, or compensation for the lost quantities due to the restriction. That Thailand did not press the EEC to recognize Thailand under the GATT as a principal supplier shows again the Thai government's perception of the insignificance of GATT provisions in strengthening its negotiating position.

Conversely, the Thai position on the tariff classification dispute shows that, after a series of domestic discussions, the government was more aware of the implications of the nomenclature issue. The EEC finally accepted the view that the 6 percent tariff should be applied to both cassava chips and pellets, but it did not extend the acceptance beyond the life of the Protocol.

In response to concerns regarding these issues, the Thai Cabinet instructed the commerce minister in May 1986 to seek agreement from the EEC to amend the Draft Protocol, though not the quota, as a precondition to the signing of the new cooperation agreement. The EEC Commission refused to modify the Draft Protocol, arguing that the Council of the EEC did not mandate any change. The parties decided on "Agreed Minutes," signed May 23, 1986, the legal status of which is less binding than an agreement.

9. Article 3(i) of the Draft Protocol states that Thai hard pellets are "those hard pellets resulting from a process in which manioc roots are first reduced to flour/meal before pelletizing." While the EEC draft claims that "pellets of flour" appear under subheading 11.04 of the CCCN, 11.04 deals with flour/meal but not pellets. Moreover, it is technically impossible to use flour to make cassava pellets, which are merely chips broken in pieces before being pelletized, in one continuous process. 
In the Agreed Minutes, the "Commission took note" of Thailand's declaration that Thai cassava pellets are not made from flour, contrary to Article 3 of the Draft Protocol. The words "took note" do not seem to place any legal obligation on the EEC, although they do permit Thailand to raise the issue in other forums without an EEC claim of estoppel. The Agreed Minutes do not resolve to Thailand's benefit, however, the issue of Thailand's status as the principal supplier. While the EEC recognizes Thailand on a bilateral level as the principal supplier of cassava under the Agreed Minutes, that is not a recognition under GATT Article XXVIII.

Thailand agrees until 1990, however, not to object to the EEC-Indonesia extended tariff unbinding agreement which recognizes Indonesia as a principal supplier, which will bar Thailand from claiming its principal supplier's status in 1989 when the EEC-Indonesia agreement expires. More important, since the EEC-Indonesia three-year extension can be renewed for another three years, it can be expected that the EEC will argue that such terms indicate a permanent unbinding permission, and that the EEC does not need to negotiate with Thailand to continue its modification of the tariff concession. An EEC letter informing the GATT that the tariff unbinding agreement with Indonesia will be extended sine die was a clear manifestation of the EEC's legal position (GATT 1986a, 1986b). The letter was circulated by the GATT; the Thai government sent a protest note, which was also circulated.

It can be argued that Thailand's hesitation to apply GATT substantive provisions stems from its lack of confidence in their effectiveness, from a misconception of GATT dispute settlement as a court of law, and from an insufficient understanding of how GATT procedure works, both as it appears in written documents and in customary practices. Those espousing this view also suggest that without more expertise in international trade law, Thailand will too readily accept a bilateral settlement of trade relations, rather than use a legal framework to confront the economic, diplomatic, and legal pressures from developed countries.

Part of the problem faced by Thailand is the inadequate training of government staff for this work. An ability to effectively negotiate within the GATT framework, however, also requires an understanding of the potential benefits and costs of GATT law by those to whom the negotiators are held accountable-ministers, parliament, and the public. Part of the problem must also be the GATT's abstruseness, which demands a level of expertise that developing countries, including Thailand, can ill afford.

\section{The Rice Title of the U.S. Food Security Act of 1985}

\section{World Rice Trade Prior to 1985}

Two exporters, the United States and Thailand, have dominated world rice trade since the late 1970s. Table 1 sets out the volume and relative shares of the 
Table 1. Relative Shares of the United States and Thailand in World Rice Exports

\begin{tabular}{|c|c|c|c|c|c|}
\hline \multirow{2}{*}{$\begin{array}{c}\text { Year } \\
\text { (three-year } \\
\text { moving } \\
\text { average) }\end{array}$} & \multicolumn{2}{|c|}{ United States } & \multicolumn{2}{|c|}{ Thailand } & \multirow{2}{*}{$\begin{array}{c}\text { Total U.S. and } \\
\text { Thai share } \\
\text { of world } \\
\text { exports }\end{array}$} \\
\hline & $\begin{array}{c}\text { Thousands } \\
\text { of tons }\end{array}$ & $\begin{array}{l}\text { Percentage } \\
\text { of world } \\
\text { exports }\end{array}$ & $\begin{array}{c}\text { Thousands } \\
\text { of tons }\end{array}$ & $\begin{array}{l}\text { Percentage } \\
\text { of world } \\
\text { exports }\end{array}$ & \\
\hline 1976 & 2,118 & 24.13 & 1,906 & 21.72 & 45.85 \\
\hline 1977 & 2,187 & 22.94 & 2,119 & 22.23 & 45.17 \\
\hline 1978 & 2,265 & 21.12 & 2,395 & 22.33 & 43.46 \\
\hline 1979 & 2,503 & 21.89 & 2,323 & 20.32 & 42.20 \\
\hline 1980 & 2,751 & 21.83 & 2,815 & 22.34 & 44.18 \\
\hline 1981 & 2,824 & 22.50 & 3,123 & 24.88 & 47.38 \\
\hline 1982 & 2,608 & 21.24 & 3,456 & 28.15 & 49.39 \\
\hline 1983 & 2,315 & 18.57 & 3,949 & 31.67 & 50.23 \\
\hline 1984 & 2,153 & 17.38 & 4,159 & 33.58 & 50.97 \\
\hline
\end{tabular}

Source: U.S. Department of Agriculture.

two in total world rice trade. Rice prices peaked in 1980 and 1981, (see figure 1), ending the period since 1973 in which nominal rice prices rose sharply.

In retrospect, the miniboom of 1980-81 can be seen as a fluctuation caused by a shortfall in production in the Republic of Korea. More important, Indonesia, the largest rice importer throughout the 1970 s, was so successful in its production drive after 1977 that its imports dropped to zero by 1984 . The peak prices of 1980 and 1981 hid these weaknesses in export markets, particularly for the U.S. rice industry, but they became apparent in the 1980s. The rising nominal prices fueled a boom in land prices in the United States, which could not be sustained when rice prices decreased. Meanwhile in Asia, where 90 percent of rice is produced and consumed, the increased output caused by the Green Revolution continued.

In 1981, the U.S. Congress did not recognize these fundamental changes in international rice markets, and in passing the quinquennial farm legislation it set the rice support price (the loan rate discussed below) at a level which was not unreasonable given past market performance. By mid-1982, however, U.S. prices fell to the level of the effective support price (see figure 1). Unlike in the EEC, the United States had no export subsidy scheme, so that U.S. export quotations remained at the support price level. At the same time, Thai export prices fell continually, the only action taken by the Thai government being a steady reduction in its export tax. The differential between Thai rice $(100$ percent 2 nd quality) and U.S. rice (No. 2) widened from about 15 percent to 80 percent. As a consequence the share of U.S. exports gradually declined while the Thai share increased.

\section{The Rice Title of the U.S. Food Security Act of 1985}

The framers of the rice title of the U.S. Food Security Act of 1985 (United States 1985) appear to have had one central aim: to prevent the lessons of the 
Figure 1. U.S. Paddy and Thai Rice Prices and the U.S. Rice Loan Rates

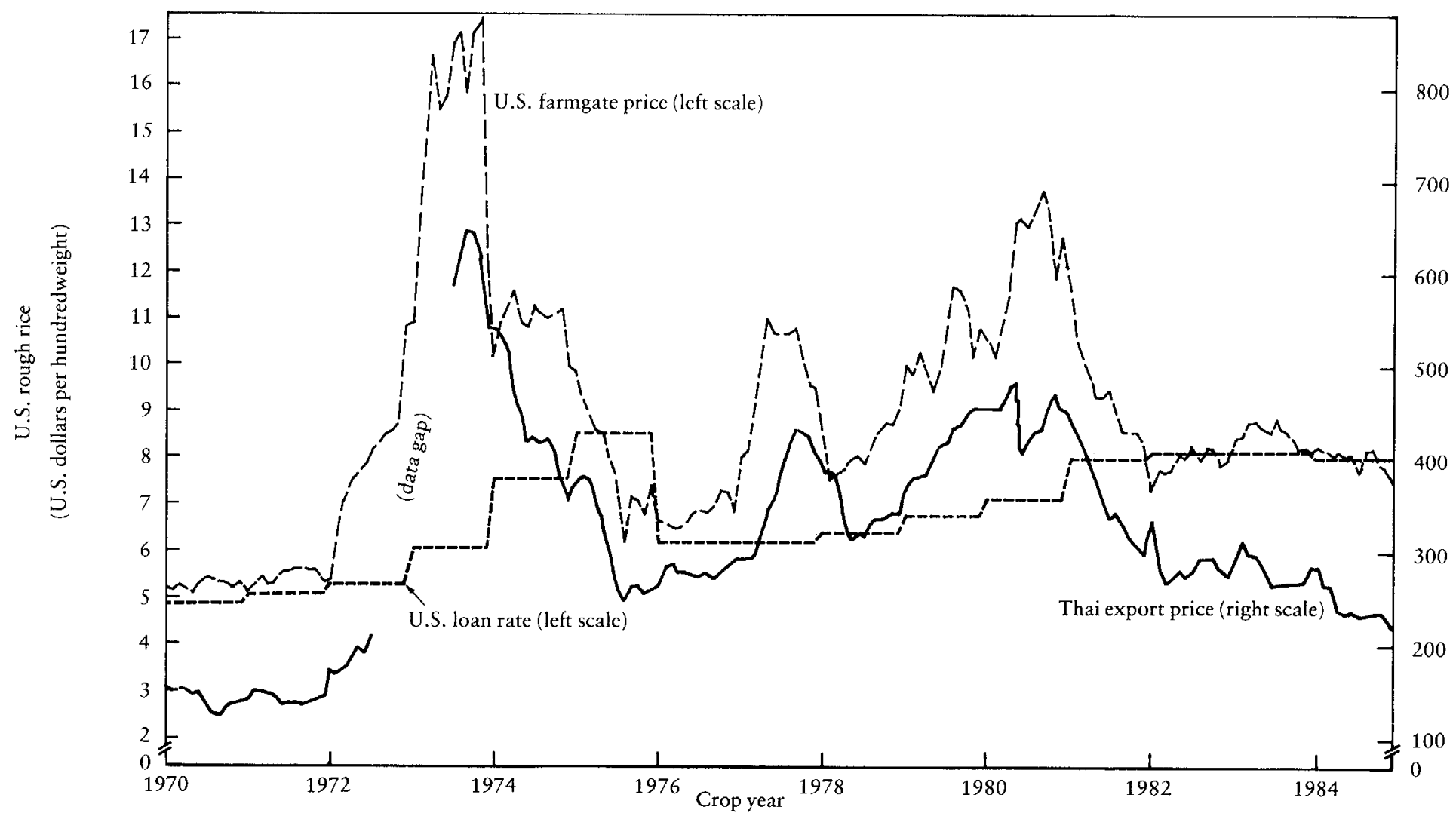

Note: Hundredweight $=100$ pounds. The U.S. price is the farmgate price for long-grain paddy (rough rice), while the Thai price is f.o.b. Bangkok for milled rice, 100 percent B grade. The original data for Thai rice were made comparable with the paddy price by using the average ratio of U.S. milled to paddy prices during 1983-84 (dividing by 2.25). The U.S. loan rate is the effective floor price created by the valuation of rice held as collateral on government loans to rice farmers, explained in the text. Sources: Foreign Agriculture Service, U.S. Department of Agriculture; Board of Trade of Thailand. 
1981-85 market which would have implied an exodus from rice production, from reaching American rice farmers. The language of the Act (particularly Section 1165) advocated that the United States should reclaim specifically from Thailand, its share of the world rice market, it being implied that Thailand was unfairly subsidizing its rice exports. As Congress was deliberating on the farm bill, the U.S. Rice Millers' Association brought a countervailing duty action against Thai rice. It was established that the Thai government subsidized rice exports by 0.75 percent. ${ }^{10}$

The cost structure of the U.S. rice production is relatively rigid and allows very little downward flexibility, and U.S. rice exporters can compete in world markets only by increasing government subsidies. This increase is what the rice title of the 1985 farm act set out to achieve.

Three administered prices are central to the U.S. subsidy system.

1. Target price. This is the price set to assure farmers that they will receive an adequate level of income. In exchange for a uniform percentage reduction (not to exceed 35 percent) in the rice area base for each farm, rice farmers belonging to the government program are assured that the rice that they produce from the permitted growing area will yield the target price. For the 1986 crop year the target price for rice was set at $\$ 11.90$ per hundredweight of rough rice, with a gradual 2-3 percent per year decline thereafter. If a farmer produces the rice and submits it as collateral for a loan (see 2 below) or sells it in the market and receives less than the target price, he is paid the difference in the form of a deficiency payment from the U.S. Treasury (not to exceed $\$ 50,000$ ).

2. Loan rate. Farmers can pledge their rice as collateral for a loan from the government; part of the loan is advanced at the time of planting. Farmers can avoid repayment by letting the government keep the rice. The collateral value of the rice paid to farmers is called the loan rate, being $\$ 7.20$ per hundredweight of rough rice for the 1986 crop. In the previous legislation the loan rate then became, in effect, the support price in the sense that the U.S. market price for rice cannot fall below it. But that role is now taken by the loan repayment rate.

3. Loan repayment rate. The farmer is not required to pay the full amount that he had borrowed from the government $(\$ 7.20$ per hundredweight in 1986), but only the portion determined by the loan repayment rate. This loan repayment rate is the greater of (i) 50 percent of the loan rate $(\$ 3.60$ per hundredweight in 1986 , to increase by 70 percent by the $1989-90$ crop years) and (ii) the "world price of rice," a notional price announced weekly by the U.S. Department of Agriculture (USDA). Since the implementation of the 1985 Act on April 15, 1986 , the loan repayment rate has fluctuated between $\$ 3.50$ and $\$ 4.12$ per hundredweight of rough rice (long-grained). Under the prior system, a farmer would only sell his rice in the market if he were able to get a price greater than the collateral value ( $\$ 7.20$ per hundredweight in 1986 ) which would then be

10. The cvD procedure does not allow the export tax, then amounting to about 5 percent of the value, to be offset against the subsidy. 
due. Under the new "marketing loan program" if a farmer is able to obtain a price greater than the repayment rate, he will profit by selling the rice and repaying at the lower rate. This then allows the U.S. floor price to decline to the level of the loan repayment rate. The counterpart of this is that the new level of the rice subsidy (the target less the repayment rate) totaled $\$ 11.90$ less (around) $\$ 4$, which is $\$ 7.90$ per hundredweight or about 198 percent of the market price.

While the deficiency payment (equaling the difference between target price and loan rate) is subject to a $\$ 50,000$ limitation, the difference between the loan and loan repayment rates was not subject to any limitation. In 1986, Congress did pass an amendment which imposed a $\$ 250,000$ limit (per farm) on all government payments other than the deficiency payment.

To implement the marketing loan program, the USDA is required to make weekly announcements of "world market prices" for long-, medium-, and shortgrained rice. Given the thinness of the world rice market, and the very broad range of qualities of rice that are actually traded in that arena, to summarize the various actual transacted prices into three statistics implies a generous amount of discretionary power for the USDA. Despite the claims made by the U.S. Agricultural Attache in Bangkok that it has not and will not use that power in a "predatory manner," it seems clear (and was admitted by the same official) that the USDA wishes the American rice exporters to recapture the "lost" market share. The weekly announcements of the world market price are one of the means to that end (Slayton 1986).

Two additional aspects of the rice title have a bearing on the analysis below. Because the loan repayment rate cannot decline below 50 percent of the loan rate, this would have imposed a new floor to the U.S. price $(\$ 3.60$ per hundredweight in 1986) and could possibly have made its rice uncompetitive again. Bent on avoiding the mistake of the 1981 Act, Congress introduced the "export marketing certificate." The administration is somewhat complicated, but this is a clear export subsidy given to exporters in an amount equal to the difference between the loan repayment rate and the world market price. This program is similar to the variable export restitution program of the EEC.

The Food Security Act of 1985 (sections 1165 [a], 1127 [a][1] and [a][3][A][i]) also contains an "export enhancement program" which allows the secretary of agriculture to embark on a subsidy war in specific markets against any country deemed to be practicing unfair trade. So far this program has not yet been applied to rice, but there is no assurance that it will not be, particularly as the U.S. Rice Millers Association has convinced the U.S. Congress that Thailand has already been proven to be subsidizing its rice exports-albeit by threequarters of one percent.

\section{Is the U.S. Rice Program Subject to International Economic Regulations?}

Remedies for injury caused by agricultural subsidies to countries exporting similar products can be based on paragraphs (1) and (3) of Article XVI of the 
GATT, as well as on the Subsidies Code which was negotiated during the Tokyo Round of multilateral trade negotiations and which elaborates on these provisions. As Thailand has not signed the Subsidies Code (although the United States has) and as the benefits under the Code are being granted by the United States only to other signatories, Thailand cannot expect to use the provisions of this Code. (It may be noted, however, that this selective application of the Subsidies Code is not accepted by all countries; some argue that the Code should be applied to all members of the GATT.)

The United States has argued that "grandfather rights" exceptions to the GATT allow their agricultural export subsidies. "Grandfather rights" here mean that all trade laws existing before the GATT came into force in 1947 remain effective even though they may be otherwise inconsistent with the GATT. It is argued that the 1985 Farm Act, seen as another five-year extension of the original Agricultural Adjustment Act of 1933, has validity despite any conflict with the GATT.

This claim has little substance because, in addition to the domestic agricultural subsidies that existed under the old Act, the 1985 Farm Act has added significant new mechanisms for subsidies covered by Article XVI (1) which cannot really be regarded as part of the old law covered by the grandfather rights exception. Furthermore, as Article XVI (3) on export subsidies was added in the late $1950 \mathrm{~s}$, it can be argued that it cannot be used as a base for grandfather rights exceptions.

Some parts of the price support under the Farm Act may be regarded as "domestic" rather than export subsidies. However Article XVI (1) of the GATT covers all forms of subsidies that adversely affect other countries. The Subsidies Code also covers all forms of export-promoting subsidies although it distinguishes between export subsidies and other subsidies (Hudec 1984). U.S. law has several provisions for remedies against the export-promoting subsidies of other countries, whether or not they are "domestic" or "export" subsidies. (Jameson 1985; Section 771 (5) (B) of Tariff Act 1930 [as amended]; United States, 1973). It is quite clear that under U.S. law, the GATT, and the Subsidies Code, the forms of price support given to U.S. rice farmers could legitimately be subject to countervailing import duties by an importing country whose domestic rice industry had been injured by imports of U.S. rice. But Thailand is a rice exporter: the key issue is whether agricultural exporters such as Thailand can rely on international trade rules to help negotiations with the United States.

\section{Using GATT Law to Tackle Export Subsidies}

Since Thailand is not a party to the Subsidies Code it cannot expect to draw on its provisions. Reliance must then be placed on Article XVI of the GatT. Article XVI (2) of the GATT seems to suggest that export subsidies should be avoided because they may have "harmful effects" for other contracting parties and may "cause undue disturbance to their normal commercial interests." Article 
XVI (1) requires subsidizing countries to notify the GATT contracting parties ${ }^{11}$ in writing of the extent, nature, and estimated effect of such a subsidy, and upon request, to meet with other contracting parties concerned in cases where such subsidization causes or threatens serious prejudice to their interests. With regard to the export subsidy of a primary product having an impact on normal competitive conditions in the world market, Article XVI (3) prohibits a contracting party from granting an export subsidy which operates directly or indirectly to increase the exports of a primary product resulting in that contracting party "having more than an equitable share of world export trade in that product." In determining the "equitable share," it states that account must be taken of "the shares of the contracting parties in such trade in the product during a previous representative period, and any special factors which may have affected or may be affecting such trade in the product."

It is very hard to pin down the scope of "more than an equitable share of world export trade." The United States has argued that its mechanisms under the Farm Act and the reduction of its rice export price to the calculated "world price" are intended merely to recapture the market it has lost to Thailand since 1982. Although the United States did lose its market share, the gain in the Thai market share was not due to a Thai export subsidy. Rather, it was due to the U.S. price support policy that lifted the prevailing U.S. price well above the Thai export price.

Articles 10 (2) and (3) of the Subsidies code attempt to shed some light on the language of Article XVI of the GATT. They read:

2. For purposes of Articles XVI: 3 of the General Agreement . . :

(a) more than an equitable share of world export trade shall include any case in which the effect of an export subsidy granted by a signatory is to displace the exports of another signatory bearing in mind the developments on world markets;

(b) with regard to new markets traditional patterns of supply of the product concerned to the world market, region or country, in which the new market is situated shall be taken into account in determining equitable share of the world export trade;

(c) a previous representative period shall normally be the three most recent calendar years in which normal market conditions existed.

3. Signatories further agree not to grant export subsidies on exports of certain primary products to a particular market in a manner which results in prices materially below those of other suppliers to the same market. [Emphasis added.]

The terms "to displace the exports of another signatory" seem to be the key to understanding the "equitable share" concept. Still, a brief survey of GATT prac-

11. The form "contracting parties" refers to GATT members acting individually. "Contracting Parties" is used in this article in place of the official GATT usage, "CONTRACTING PARTIEs," to refer to actions by signatory countries as a group. 
tices demonstrates confusion and uncertainty in the application of the equitable share concept.

There have been four GATT panel decisions on the issue of "equitable share" (Coccia 1986 pp. 16-21). The first case involved an Australian complaint in the late 1950s against the export of French wheat flour in which the panel decided that a system of refunds employed by the French acted as export subsidies (GATT 1959 , p. 46; Coccia 1986, p. 16). The panel opined that "[though] there is no statistical definition of an 'equitable' share in world exports, subsidy arrangements have contributed to a large extent to the increase in France's exports of wheat and wheat flour." The panel concludes that "the present French share of world export trade, particularly in wheat flour, is more than equitable" (GATT 1959; cited in Coccia 1986). This case seems to give us some hope that "equitable share" is something one can rely on, yet three subsequent cases discourage one's expectation.

Parallel disputes arose between the EEC and Australia and Brazil due to EEC refunds on sugar exports in the late 1970s. The GATT panels refused, however, to reach a definite conclusion because it was difficult to rule on a causal link between the increase in the EEC's market share and the decrease in the complainants' shares (GATT 1978-79; p. 290; 1979-80, p. 69; Coccia 1986, p. 16). The panel on the 1983 U.S.-EEC disputes on wheat flour also followed these precedents (Coccia 1986; pp. 17-22). It determined that the EEC share was larger because of its export subsidies payment, yet given the difficulties in application of the concept of "more than equitable share," it concluded that "despite considerable increases in EEC exports, market displacement in the sense of Article $10(2)(a)$ [of the Subsidies Code] was not evident in the seventeen markets presented by the United States and examined by the panel" (cited in Coccia 1986; p. 19).

In the case of the U.S. Rice Title, the issue of share in specific markets, as distinct from global shares, may also warrant some discussion, although GATT practice does not clarify this issue (Coccia 1986, p. 19). Although the panel in the French wheat flour case ruled that the share refers to world export trade and not individual markets, (GATT 1959; p. 52) the panels on the sugar cases, while reaffirming this rule, seriously considered the effect on individual markets in determining the displacement of exports. (Coccia 1986, p. 19). In the case of Thai rice exports, it is not at all clear which market or markets the GATT would examine in determining whether or not the United States has acquired more than an equitable share.

The foregoing overview of GATT practices raises many other uncertainties. Does "displace" mean displace partially or absolutely? Does "displace" refer only to the loss in quantity or does it encompass a situation in which Thai exporters had to sell a larger volume of rice but with a much lower price than it could have otherwise obtained, in order to survive in the export business? Furthermore, Article X (3) prohibits subsidies on certain primary products (including rice) which results in prices materially below those of other suppliers in the same 
market. It does not deal with the situation in which, although the U.S. price is not below Thai price, the difference between the two prices has been sharply reduced. It is evident that even if Thailand were a signatory to the Subsidies Code it would not receive clear and firm legal support from that Code.

The situation Thailand is facing at present is one in which subsidies from a developed country are having a clear negative effect, both in the short and long run, on Thai rice exports. The problem posed in rice is different from that in cassava. For cassava, the substantive laws are relatively clear (at least to us) that Thailand has certain specific rights, but the problems lie in the lack of confidence on how such rights are to be enforced, both at the negotiating table and in a GATT panel. The reluctance to take action over rice derives mainly from the ambiguity and uncertainty of the substantive rights provided by the law.

The ambiguity of the law, the lack of understanding of the GATT system, inexperience in resorting to the GATT, and the lack of expertise among government staff in this area, all discourage Thailand from raising the rice issue at the GATT or from relying on international trade regulations when it negotiates this case with the United States. Although the Thai government decided several months ago to bring the rice issue to the GATT, up until the time of this writing (April 1987) Thailand has taken no action in the GATT. In the absence of confidence in the GATT system, the traditional approach of diplomatic talks with the U.S. Administration and the State Department seems to override alternative forms available by which to resolve disputes in international trade.

\section{What Is To Be Done?}

The case studies discussed above argue for an adjustment in the Gatr legal system. We suggest below changes in GATT law, practice, and attitudes necessary to support equitable agricultural trade.

\section{A Change in GATT Laws: Increasing Clarity}

Thailand's experience with cassava and rice demonstrate that the ambiguity in GATT substantive laws on agriculture discourages agricultural exporters and particularly developing countries from resorting to GATT laws when negotiating with other countries. A clear example is provided by the provisions concerning subsidization for which the Subsidies Code is of little help, even for signatories.

On the procedural side of the law, there should be clarification of steps to be taken to obtain enforcement of substantive rights stipulated by GATT laws. For example, a GATT Code could spell out steps negotiating parties must take to modify their commitments in accordance with Article XXVIII. When and how should parties inform the GATT of their agreement under Article XXVIII? What if the party wishing to modify concessions seeks agreement with a country which is not a principal supplier? Will the GATT reject the notice because that party is clearly not the actual principal supplier? Does the principal supplier have to take the initiative to protest to the GATT? If the GATT circulates a letter of protest and 
the party modifying the concession does not respond, what is the status of each party in that situation? These questions reflect points of concern of the Thai government in the cassava case.

Another example often cited in current GATT literature is the unclear dispute settlement process. The Thai and other governments have serious doubts about how to implement the principles and procedures embodied in Articles XXII (consultation) and XXIII (nullification and impairment) of the GATT. Greater clarity and discipline are necessary to increase confidence in GATT rules and procedures. Moreover, there should be a time limit stipulated for dispute settlement by conciliation or panel decision. The delay in the judicial procedure, for example, is extremely costly for traders and itself becomes a barrier to trade. In the cassava case, fears that delays in the GATT legal process would damage Thai interests discouraged Thailand from even advocating the Thai position in the GATT. The reporting and recording of the results of consultations and of the rationale of panel decisions could be greatly improved. This does not imply that the doctrine of precedent is introduced because trade issues are generally accepted as having a very ad hoc nature. Rather, such rationales should serve as authoritative interpretation or guidelines for the application of GATT laws and thus as a basis for trade policy planning.

International customary law-that which requires a proof of the state's practices accepted as law-could play a more active role in the GATT legal framework. Article $38(1)(b)$ of the Statute of the International Court of Justice states that customary law is one of the sources of international law. International customary law has served as the basis for normative rules, especially in those areas where a written law (for example a treaty) does not exist or exists but is regarded as a "soft" law. The law of the merchant (Lex Mercatoria), which derives from customary practices among traders, is an extremely important source of law governing commercial transactions (Berman and Kaufman 1978, pp. 224-29). Customary law would not change, but merely supplement the law of the GATT.

Related to this, the GATT Contracting Parties, with help from experts or panels, could play an active role in interpreting ambiguous provisions or rules. Such interpretations could be binding upon the contracting parties. The Contracting Parties adopted a procedure to allow the director-general of the GATT to use his good offices to facilitate a solution to a dispute between a developed and a developing country (GATT 1966, p. 18). The GATT Secretariat also could be formally encouraged to assist in the dispute settlement process.

\section{A Change in GATT Practice: Dealing with Voluntary Export Restraints}

As developed countries increasingly demand that they be allowed to withdraw tariff concessions on agricultural (and other) products, an effective process is needed for dealing with the demands for VER which frequently arise with these modifications. While the GATT has ignored VERs in the past, new provisions are 
needed to strengthen the bargaining power of developing countries facing pressures to adopt vers.

Some authors have proposed the outlawing of VERS (GATT 1985) by the GATT. Others have proposed the legalization or regulation of VER within the GATT framework. Both proposals could be counterproductive to the interests of developing countries. The elimination of vERs is an unrealistic aim and would take away some economic benefits that can go to developing countries in the absence of a free trade regime. (Hindley 1980; see also his article in this volume). Conversely, the legalization of VERs under the GATT could eviscerate the legal framework of the GATT, or "gut the GATT," in Wijkman's words (Wijkman 1986). It would undermine the nondiscrimination principle which has been a GATT cornerstone and superimpose another trade regime on the GATT legal framework (as the Multifibre Arrangement has done).

The Thai-EcC cassava case suggests that a link between vers and the GATT could benefit developing countries. For example, greater clarity regarding the steps to be taken under Article XXVIII, to determine the principle supplier and to reject an incorrect procedure would have assisted Thailand in its negotiations with the EEC. Thailand could then have sought better terms for its VER if the EEC had still sought to modify the concession. Good faith negotiations would have been facilitated had the GATT decided officially that Thailand was the principal supplier of cassava, and that the EEC unbinding of 1982 was temporary.

\section{A Change in GATT Attitudes}

Our final proposal concerns the need for a change in the GATT's approach to exceptions to GATT laws and to the style of negotiation and dispute settlement it encourages. Both attitudinal changes would benefit developing country parties, the first allowing them to attain compensation for exceptions, and the second increasing the discipline of and the number and type of forums for negotiation.

The role of exceptions. Many have complained that exceptions have smothered principles in the GATT. Teese observed that the GATT "[is] no longer a legal framework for international trade but rather a set of principles more honored in the breach than in the observance." (Teese 1982).

Exceptions are important in international system. They constitute a means to build up more rules (Wijkman 1986, p. 39). A country is willing to undertake and honor principles if it knows that it can waive its commitments when circumstances change..$^{2}$ Article XXVIII is a good example of this. In this sense, exceptions help increase the individual states' willingness to accept rules and thus increase their participation in the GATT system. At present, exceptions to the GATT are tolerated and obligations under the exceptions are generally expected

12. The principle of change of circumstance derives from the universal rebus sic stantibus principle, which allows a state to renegotiate or to break a treaty if there is a situation which, had it existed at the time of the signing, would have precluded the treaty (or contract) (see also Vienna Convention on the Law of Treaties 1969, in Brownlie 1978). 
to be upheld. This tolerance of exceptions reflects the norms of the Contracting Parties. For developing (and other) countries to be successful in agricultural trade negotiations, they have to learn to utilize exceptions to the GATT to their benefit. The U.S. grandfather rights exception to the GATT, the VER arrangements by the EEC on agriculture with developing countries or the blind eye turned toward outright violations of GATT principles cannot be terminated overnight.

The GATT should increase the costs of invoking an exception, providing bargaining power for those adversely affected by these exceptions. For example, the compensatory adjustment under Article XXVIII should be obligatory, and the obligation to seek agreements with the three groups of suppliers before any unbinding can be made should be supervised and monitored. Amendments should probably also be introduced to allow discriminatory retaliation against unilateral withdrawal of concessions limiting the retaliation to the withdrawing country. Generally, mechanisms outside the defined scope of exceptions should be compensated.

Conciliatory versus adversarial styles for the GATT. Perceptions of the GATT vary a great deal, ranging from the view of the GATT as a court in international trade, to GATT as a "General Agreement to Talk and Talk." The first views GATT dispute settlement procedure as adversarial and somewhat courtlike. This is the position usually advocated by the United States. The other views it as conciliatory and accommodating. This latter view is supported by the EEC. (Ehrenhaft 1986; Phan 1986). Despite those differences, both views do suggest that the GATT appears to give something to countries that they would not otherwise obtain. As for the Thai government, although it is inclined toward the EEC view, it appears to dismiss the GATT as merely "a paper tiger," as was expressed during debates over the cassava issue. The GATT is extremely weak in some areas, but it is also true that there are many aspects of the GATT that contribute significantly to international trade. There have been an increasing number of GATT panels over the last decade, and countries including the United States, the EEC, and Japan, are willing to abide by at least some panel decisions (Ehrenhaft 1986, p. 149)..$^{13}$

Despite vast differences, the central goal for the GATT, in most eyes, remains to set guidelines for international trade and resolve problems arising therefrom. We do not wish to emphasize the enforcement aspect of international law because its "horizontal enforcement" nature (enforcement among equals) is necessarily more complex than and different from the "vertical enforcement" nature of the domestic legal system (which invokes the higher power of the state). Rather we would like to see a more disciplined yet not always adversarial dispute settlement procedure. It should be sufficiently disciplined to ensure that an

13. For example, the EEC adopted the panel findings that it had violated the Government Procurement Code. The Unired States accepted that the Manufacturing Clause of 17 USC Section 601 on the printing of copyrighted books violated the National Treatment principle set forth in provisions of GATT Article III. 
economically weaker country can clearly foresee possible benefits from settling disputes in the international forum, especially where that country has a strong legal position. For the GATT to serve its purpose and achieve that goal, both GATT and participants in the GATT system need to adjust some of their attitudes.

First, just because the GATT is more than a messenger between parties in a trade dispute does not make the GATT a world trade court. It is one thing to act as a judge in a case which has winning and losing parties. It is quite another thing to give a ruling to facilitate good faith negotiations. The ruling may cover such things as who is the principal supplier or whether a particular unbinding is temporary or permanent. Such facilitation should become a part of the GATT framework for trade negotiations.

Second, the GATT does not have to define its role precisely. Robert Hudec once observed:

[T]he force of GATT legal rules has always been particularly dependent on the force of the normative consensus they represent . . . Having been cast in a less rigorous form, GATT rules must necessarily draw the major part of their authority from their consistency with the norms and values current in the GATT community. [Emphasis added; cited in Phan 1986.]

Accommodating many views does not necessarily imply intellectual flabbiness. The GATT could command the faith and confidence of its members by providing them with precisely outlined choices of dispute settlement processes. The fully flexible consultation process in Article XXII could still exist, but with more specific guidelines regarding procedure. The role of the director-general in helping to solve disputes, similar to the U.N. charter provisions for its Secretarygeneral, could be spelled out. Choices of mediation, conciliation, and arbitration which require third party involvement could be given, and the procedures for each clearly laid down. Finally, a rigid procedure involving an adversarial forum or a courtlike dispute settlement can also be contemplated in the framework of GATT panels.

Such changes will never be accomplished if both the GATT and its members do not adjust their attitudes toward the GATT system. The GATT does not have to be one thing or the other, and cannot be all, yet the GATT can provide choices encompassing most views that are evidently the "values" in the GATT community at the moment. A country having faith or experience in a particular approach can follow that route. The key is that the system must provide a certain level of certainty as to where people go in each choice, and how the GATT can assist in such processes. Here again, the GATT's willingness and ability to state what its law means or says substantively and procedurally could be of great help.

In summary, we wish to emphasize the necessary changes which will make specific, bilateral agricultural trade negotiation under the GATT (not in the MTN), and probably other negotiations as well, more beneficial to all parties. There is a need to clarify some unnecessarily vague substantive provisions, to widen choices of dispute settlement, to be willing to give judgment on some technical 
legal or factual issues, and to regard GATT provisions as negotiating tools inter alia in the context of vers. These are issues that the new MTN round could accommodate its agenda. The suggested changes not only require amendments of GATT provisions, they also require more complicated and sensitive changes in practice and attitudes. These cannot change overnight by issuing a new law, but require the participation of developing countries whose view of law may be different from that of the developed countries. Finally they require that the GATT mobilize opinions internally and among its members before changes can be adopted that will reflect internationally shared values and norms.

\section{REFERENCES}

Australia, Commonwealth of. 1985. Agricultural Policies in the European Community: Their Origins, Nature and Effects on Production and Trade. Bureau of Agricultural Economics Policy Monograph 2. Canberra: Australian Government Publishing Service.

Berman, Harold J. and Colin Kaufman. 1978. "The Law of International Commercial Transactions (Lex Mercatoria)." Harvard International Law Journal 19, no.1.

Brownlie, Ian. Ed. 1978. Basic Documents in International Law. 2 d ed. London: Oxford University Press.

Coccia, Massimo. 1986. "Settlement of Disputes in GaTt under the Subsidies Code: Two Panel Reports on EEC Export Subsidies," Georgia Journal of International and Comparative Law 16: 16-22.

Ehrenhaft, Peter D. 1986. “A U.S. View of the GATT.” International Business Lawyer 14, no. 5 (May): 147-49.

European Economic Community. 1982a. "Agreement in the form of an exchange of letters between the European Economic Community and the Federal Republic of Brazil.” Official Journal of the European Communities L 219 (July, 28 1982): 58+59.

- 1982b. "Agreement in the form of an exchange of letters between the European Economic Community and the Republic of Indonesia." Official Journal of the European Communities L 219 (July 28): 56-7.

-1982c. "Cooperation Agreement between the European Community and the Kingdom of Thailand on Manioc Production, Marketing and Trade." Official Journal of the European Communities L 219 (July 28): 53-4.

Friedman, Wolfgang, Louis Henkin, and Oliver Lissitzyn. 1972. Transitional Law in a Changing Society. New York: Columbia University Press.

GatT (General Agreement on Tariffs and Trade). 1959. "French Assistance to Exports of Wheat and Wheat Flour." Basic Instruments and Selected Documents (7th supplement).

__. 1966. Special Dispute Settlement Procedure. Basic Instruments and Selected Documents (14th supplement).

- 1978-79. EEC-Refunds on Exports of Sugar-Complaint by Australia. Basic Instruments and Selected Documents (26th supplement).

- 1979-80. EEC-Refunds on Exports of Sugar-Complaints by Brazil. Basic Instruments and Selected Documents (27th supplement). 
1982. Letter from the Delegates of the European Economic Community and Indonesia to the Director-General of the GATT Secretariat, dated July 20,1982.

1985. Trade Policies for a Better Future: Proposals for Action, Geneva.

—. 1986a. Circulation Documents No. 121 SECRET/259/ADD.4. Dated March 6, 1986.

- 1986b. Circulation Documents No. 121/SECRET/259/ADD.4/CORR 1. Dated March 27, 1986.

Hartwig, Bettina, and Stefan Tangermann. 1987. Legal Aspects of Restricting Manioc Trade between Thailand and the EEC. Kiel: Wissenschaftsverlag Vauk.

Hindley, Brian. 1980. "Voluntary Export Restraints and the GATT's Main Escape Clause." World Economy 3, no.3 (November): 313-41.

Hudec, Robert E. 1984. "Regulation of Domestic Subsidies Under the MTN Subsidies Code." In D. Wallace, F. Loftus, and V. Krikorian, eds., Interface Three: Legal Treatment of Domestic Subsidies. Washington, D.C.: International Law Institute.

Jameson, Paul W. 1985. "The Administration of the U.S. Countervailing Duty Law with respect to Domestic Subsidies: Where It's Been, Where It Is, Where It May Go." Syracuse Journal of International Law and Commerce 12, no. 1 (Fall): 59-124.

Koester, Ulrich. 1982. Policy Options for the Grain Economy of the European Community: Implications for Developing Countries. Research Report 35. Washington, D.C.: International Food Policy Research Institute.

Phan van Phi, R. 1986. "A European View of the GATT." International Business Lawyer 14, no.5 (May): $150-51$.

Ritson, Christopher, and Stefan Tangermann. 1979. "The Economics and Politics of Monetary Compensatory Amounts." European Review of Agricultural Economics 6, no.2: 119-64.

Schachter, Oscar. 1977. Sharing the World's Resources, New York: Columbia University Press.

Slayton, Thomas. 1986. "Effects of Farm Act on Thai Rice." The Nation, July 3, 1986.

Teese, Colin F. 1982. "A View from the Dress Circle in the Theater of Trade Disputes." World Economy 5, no.1 (March): 43-60.

United States. 1973. "X-Radial Steel Belted Tires from Canada." Federal Register 38, p. 1018.

- 1985. "Proceedings and Debates of the 99th Congress, First Session." Congressional Record 131, no. 175, part II, section 17.

Walker, Herman. 1964. "Dispute Settlement: The Chicken War." American Journal of International Law 58, no. 3: 671-85.

Wijkman, Per Magnus. 1986. "Informal Systemic Change in the GatT." World Economy 9, no.1 (March): 37. 